\title{
Comparison and optimization of different methods for Microcystis aeruginosa's harvesting and the role of zeta potential on its efficiency
}

\author{
Pedro Geada ${ }^{1}$ (D) Francisca Oliveira ${ }^{1} \cdot$ Luís Loureiro $^{1} \cdot$ Diogo Esteves $^{1} \cdot$ José A. Teixeira ${ }^{1} \cdot$ Vítor Vasconcelos $^{2}$. \\ António A. Vicente ${ }^{1} \cdot$ Bruno D. Fernandes ${ }^{1}$
}

Received: 27 November 2018 / Accepted: 6 March 2019 / Published online: 16 April 2019

(C) Springer-Verlag GmbH Germany, part of Springer Nature 2019

\begin{abstract}
This study has compared the harvesting efficiency of four flocculation methods, namely, induced by $\mathrm{pH}, \mathrm{FeCl}_{3}, \mathrm{AlCl}_{3}$ and chitosan. No changes were observed on M. aeruginosa cells. Flocculation assays performed at $\mathrm{pH} 3$ and 4 have shown the best harvesting efficiency among the $\mathrm{pH}$-induced tests, reaching values above $90 \%$ after $8 \mathrm{~h}$. The adjustment of zeta potential (ZP) to values comprised between -6.7 and $-20.7 \mathrm{mV}$ enhanced significantly the settling rates using flocculant agents, being $\mathrm{FeCl}_{3}$ the best example where increments up to $88 \%$ of harvesting efficiency were obtained. Although all the four methods tested have presented harvesting efficiencies above $91 \%$ within the first $8 \mathrm{~h}$ after the optimization process, the highest performance was obtained using $3.75 \mathrm{mg} \mathrm{L}^{-1}$ of $\mathrm{FeCl}_{3}$, which allowed reaching $92 \%$ in $4 \mathrm{~h}$.
\end{abstract}

Keywords Induced flocculation $\cdot$ Zeta potential $\cdot$ Harvesting efficiency $\cdot$ Microcystis aeruginosa

\section{Introduction}

The continuous deterioration of water supplies represents an emerging threat for all human beings which might, in a near future, lead to higher scarcity of potable water. Although climate changes are, at some extent, responsible for water impairment, anthropogenic stresses, such as intensive agriculture, and the industrial and technological era we are living in nowadays, are also causing serious damage to numerous freshwater and marine water bodies. One of the greatest concerns arising from this careless behavior is the widespread occurrence of cyanobacterial blooms across the globe, frequently resulting from eutrophication of water (Geada et al. 2017; Harke et al. 2016; Moreira et al. 2013; Paerl et al. 2001).

Responsible editor: Philippe Garrigues

Pedro Geada

pedrogeada@ceb.uminho.pt

1 CEB-Centre of Biological Engineering, University of Minho, Braga, Portugal

2 Department of Biology, Faculty of Sciences, CIIMAR/CIMAR Interdisciplinary Centre of Marine and Environmental Research and, University of Porto, Porto, Portugal
The capacity to produce potent toxins, together with the extensive surface scums formed by these organismscommonly known as harmful algal blooms (HABs) - make them a great public health problem especially when it occurs in drinking water sources and aquatic recreational areas (Giannuzzi et al. 2011; Merel et al. 2013). Microcystin (MC), a hepatotoxin produced, among others, by Microcystis aeruginosa, was the cause of the worst recorded incident when dozens of patients died in Brazil because of the use of contaminated water during their hemodialysis procedure (Jochimsen et al. 1998).

Owing to the presence of intracellular toxins such as MCs, the removal process of toxin-producing cyanobacteria should be carried out under mild conditions to prevent the release of toxic compounds from the cells and, consequently, the contamination of water (Zamyadi et al. 2012). However, some of the techniques currently applied in the treatment of water containing cyanobacteria might damage or at least compromise cells' membrane (Ma et al. 2012; Mucci et al. 2017; Sun et al. 2012). Thus, supplementary methods may be needed to promote cyanotoxins' decomposition, which increases significantly the overall cost of the process (Geada et al. 2017; Oberholster et al. 2004). Although numerous studies have been performed to assess the removal efficiency of $M$. aeruginosa, including the use of magnetic particles 
(Jiang et al. 2010; Lin et al. 2015), coagulant/flocculant agents (Lürling et al. 2017; Ma et al. 2016; Qi et al. 2016; Shi et al. 2016; Wang et al. 2015; Yuan et al. 2016; Zhou et al. 2014), ultrasounds (Rodriguez-Molares et al. 2014), and flotation (Yap et al. 2014), none of those presented a comparison between techniques. One of the few exceptions, conducted by Teixeira and Rosa (2007), showed that the best harvesting efficiencies (HEs) were obtained using coagulation/flocculation/ dissolved air flotation when compared to coagulation/flocculation/sedimentation process. Furthermore, the flocculation solely induced by the variation of $\mathrm{pH}$ is still poorly understood and might represent a promising technique since no additional compounds, such as coagulants, are required. The surface of $M$. aeruginosa cells generally presents negative charge for a wide range of $\mathrm{pH}$ values (Hadjoudja et al. 2010), which enables their suspension as individual cells. However, variations on the $\mathrm{pH}$ of the surrounding environment might lead to the destabilization of the charge of membrane and, consequently, to the aggregation of cyanobacteria (and formation of flocs).

In contrast to the problematic presence of toxins in drinking water, some of these compounds are drawing attention of researchers from medical fields once several interesting bioactivities were found in these secondary metabolites (Geada et al. 2017). The aforementioned MC, for instance, was demonstrated to treat/reduce some of the Parkinson's disease symptoms and to be a promising anticancer drug (Braithwaite et al. 2012; Ilić et al. 2011; Niedermeyer et al. 2014; Zanchett and Oliveira-Filho 2013). Therefore, also in this case, decreasing losses of cyanotoxins during the harvesting process of cyanobacteria are desired so that the production cost of these compounds is reduced and their commercialization becomes more feasible.

The aim of this study was to compare the efficiency on the removal of $M$. aeruginosa of four different harvesting methodologies - the use of the well-known flocculant agents, i.e., aluminum chloride $\left(\mathrm{AlCl}_{3}\right)$, iron chloride $\left(\mathrm{FeCl}_{3}\right)$, and chitosan $(\mathrm{Ch})$ and $\mathrm{pH}$-induced flocculation. The influence of zeta potential (ZP) was also assessed and an optimization of all methods was performed.

\section{Materials and methods}

\section{Microorganism culture and cyanobacterial suspension preparation}

Microcystis aeruginosa LEGE 91094, a unicellular cyanobacterium, was kindly provided by the Interdisciplinary Centre of Marine and Environmental Research collection (CIIMAR Porto, Portugal) and maintained in Z8 medium (Kotai 1972) at $20{ }^{\circ} \mathrm{C}$ and $\mathrm{pH} 8.7$ under $10 \mu \mathrm{mol} \mathrm{m} \mathrm{m}^{-2} \mathrm{~s}^{-1}$ of light intensity using a 12:12-h L:D cycle. Cultures were aerated ( 0.38 vvm) and renewed every month. Cyanobacterial cells were washed with distilled water (10,394 g, $15 \mathrm{~min}$ ) before the preparation of each assay in order to ensure the same initial culture conditions. Cells were then resuspended with distilled water and biomass concentration was fixed at $0.5 \mathrm{~g} \mathrm{~L}^{-1}$.

\section{pH-induced flocculation optimization}

Flocculation induced by $\mathrm{pH}$ was tested for values ranging from 1 to 12, and the experiments were conducted in duplicate for $24 \mathrm{~h}$ using glass test tubes containing $42 \mathrm{~mL}$ of culture. The $\mathrm{pH}$ of the assays was adjusted utilizing $\mathrm{NaOH}(0.5$ and $\left.1 \mathrm{~mol} \mathrm{~L}^{-1}\right)$ and $\mathrm{HCl}\left(1\right.$ and $\left.2 \mathrm{~mol} \mathrm{~L}^{-1}\right)$. Samples were drawn at the intermediate point between the surface of the culture and the bottom of the test tube. When cultures were set for the harvesting efficiency assessment (with $\mathrm{pH}$ adjustment done), a vigorous agitation was carried out to obtain a homogeneous solution and initiate, subsequently, the process.

\section{Comparison of harvesting methods}

After selecting the $\mathrm{pH}$ responsible for the most efficient flocculation, a comparison was performed using three different flocculant agents: $\mathrm{AlCl}_{3}, \mathrm{FeCl}_{3}$, and chitosan (Ch). These techniques were carried out using the optimal concentrations reported in Sun et al. (2012), Chow et al. (1998), and Pei et al. (2014), respectively. According to the instructions presented by those references, the $\mathrm{pH}$ of the assays using $\mathrm{FeCl}_{3}$ and chitosan were adjusted to 8.2 and 8.0 , respectively, before the addition of the coagulants, while the use of $\mathrm{AlCl}_{3}$ did not require any $\mathrm{pH}$ adjustment. The assays were followed during $24 \mathrm{~h}$ and done in duplicate as described in the " $\mathrm{pH}$-induced flocculation optimization" section. As explained in the previous section, after the coagulant agent was added, cultures were agitated vigorously as well before the assessment of harvesting efficiency took place.

\section{Optimization of harvesting methods using ZP as an indicative tool}

Li et al. (2015) have carried out a study where a specific optimal interval of values of ZP (OIVZP) between -6.7 and $-20.7 \mathrm{mV}$ was found to improve HE during chitosanmodified soil-induced flocculation. Therefore, we decided to assess the influence of this parameter on harvesting by varying either the amount of $\mathrm{AlCl}_{3}, \mathrm{FeCl}_{3}$, and $\mathrm{Ch}$ applied on treatment or the $\mathrm{pH}$ of the culture.

\section{Analytical methods}

HE was determined by measuring the optical density of the culture $(200 \mu \mathrm{L})$ at $750 \mathrm{~nm}$ (Griffiths et al., 2011) in a Synergy $^{\text {TM }}$ HT Multi-Detection Microplate Reader (BioTek Instruments, Inc., USA) according to Eq. 1: 
Fig. 1 Assessment of $\mathrm{HE}$ on $\mathrm{pH}-$ induced flocculation experiments $(n=2)$ (control ( $\square), \mathrm{pH} 1(\square)$,

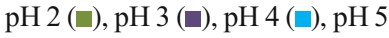
$(\square), \mathrm{pH} 6(\square), \mathrm{pH} 7(\square), \mathrm{pH} 8(\square)$,

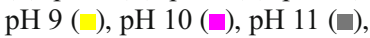
pH 12 (ם)). Error bars correspond to minimum and maximum values

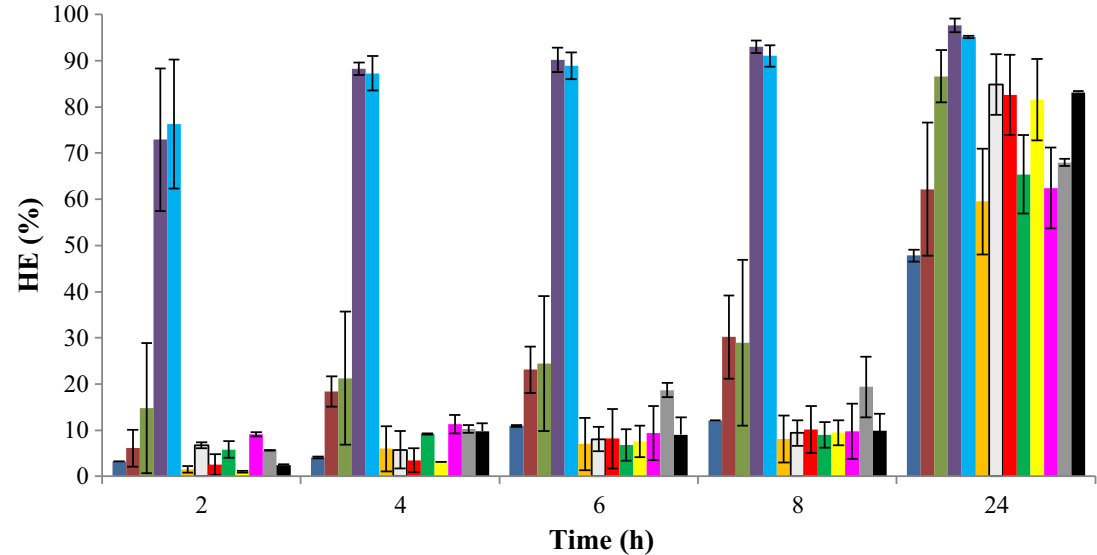

$H E \%=\frac{O D_{0}-O D_{t}}{O D_{0}} \times 100 \%$

where $O D_{0}$ refers to the optical density $(750 \mathrm{~nm})$ measured at the beginning of the process and $O D_{t}$ is the optical density $(750 \mathrm{~nm})$ after a certain period of time $(t, \mathrm{~h})$.

All the experiments were analyzed by flow cytometry (EC800 Flow Cytometer Analyser, Sony Biotechnology Inc., USA) to ensure that no damage was inflicted to cells during harvesting methods, and no significant changes in terms of size, membrane complexity, and viability were observed. In order to have a certain confidence level of cell concentrations and consistent fluorescence results, a total of $50 \mu \mathrm{L}$ was taken for each triplicate of the samples. The number of events and fluorescence signals of the long pass filter (665 nm, fluorescent red signal), FL3, were evaluated by EC800 1.3.6 analysis software (Sony Biotech) and the Flowing software 2.5.1.

The same conclusions were drawn by evaluating the absorbance of supernatant (at $254 \mathrm{~nm}$ ) with a Synergy ${ }^{\mathrm{TM}}$ HT MultiDetection Microplate Reader (BioTek Instruments, Inc., USA) in order to determine the amount of intracellular organic matter released. The supernatant was collected after harvesting methods were applied by centrifuging the cultures at $13,548 \mathrm{~g}$ for $5 \mathrm{~min}$.

$\mathrm{ZP}$ was also determined in triplicate for all tests performed using a Zetasizer Nano-ZS (Malvern Instruments Ltd., UK). For that purpose, samples of $0.8 \mathrm{~mL}$ were withdrawn from the assays after $2,4,6,8$, and $24 \mathrm{~h}$ of treatment, agitated manually and subsequently used to measure ZP.

\section{Results and discussion}

\section{Optimization of pH-induced flocculation}

$\mathrm{pH}$-induced flocculation assays were carried out in order to study the harvesting efficiency of M. aeruginosa (Fig. 1).
According to Fig. 1, the highest HEs were obtained by adjusting $\mathrm{pH}$ values to 3 and 4, resulting in a sedimentation of more than $90 \%$ of M. aeruginosa cells after $8 \mathrm{~h}$ of treatment. This behavior is in accordance with findings reported by Liu et al. (2013) for three different freshwater microalgae: Chlorococcum nivale, C. ellipsoideum, and Scenedesmus sp. Although the optimal $\mathrm{pH}$ interval suggested by these authors is in agreement with our results, other studies presented completely different results. This is the case of $\mathrm{Wu}$ et al. (2012) who have tested flocculation induced by $\mathrm{pH}$ in three freshwater microalgae (among which were Chlorococcum sp. and Scenedesmus sp.) as well as two marine species. Alkaline environments, especially above $\mathrm{pH} 9$, were frequently considered the most suitable conditions to reach the most efficient flocculation processes (Wu et al. 2012). The variations found in these works indicate that the success of $\mathrm{pH}$-induced flocculation methods is strongly dependent on the strain studied.

The lowest efficiency of the control group at $24 \mathrm{~h}$ is probably due to the great stability of the cells since no $\mathrm{pH}$ adjustment was made and, consequently, no addition of $\mathrm{NaOH}$ and $\mathrm{HCl}$ has occurred. Maintaining the original surface charge, M. aeruginosa cyanobacteria stay in suspension as individual cells and do not form flocs (caused by aggregation), presenting therefore lower sedimentation rates.

As mentioned previously in this section, changes in $\mathrm{pH}$ of the environment entail a series of modifications, being ZP one of the properties significantly affected by those. Figure 2 presents the differences observed for ZP of M. aeruginosa when $\mathrm{pH}$ of the medium ranges from 1 to 12 .

Through Fig. 2, it is possible to see that both assays where highest HEs were observed, carried out at $\mathrm{pH} 3$ and 4, presented ZP values comprised in the OIVZP. pH 4 was selected as optimal value to induce $M$. aeruginosa flocculation.

\section{Comparison of HE}

After the optimization of $\mathrm{pH}$-induced flocculation process for M. aeruginosa $(\mathrm{pH}=4)$, and using the optimal concentrations 


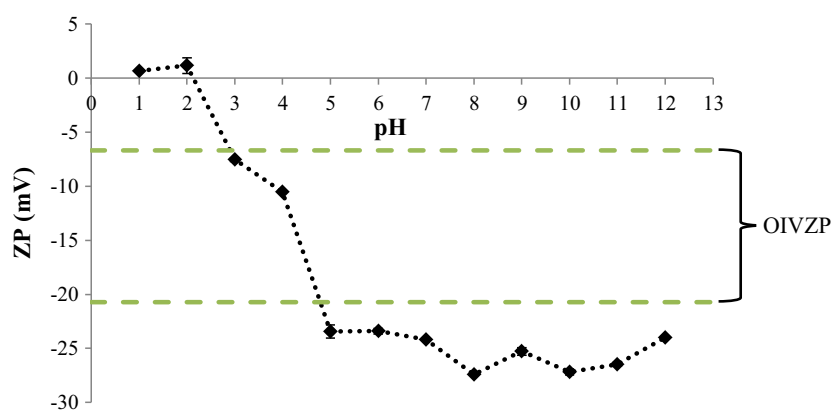

Fig. 2 Variation of ZP of M. aeruginosa at different $\mathrm{pH}$ values $(n=3)$. Green dashed lines (-) represent the optimal interval of values for the zeta potential (OIVZP) for flocculation, according to Li et al. (2015). Error bars correspond to the standard deviation of the average value determined for triplicates

defined in the bibliography (Sun et al. 2012; Chow et al. 1998; Pei et al. 2014) for $\mathrm{AlCl}_{3}, \mathrm{FeCl}_{3}$, and $\mathrm{Ch}-15,30$, and $7.31 \mathrm{mg} \mathrm{L}^{-1}$, respectively (cf. "Comparison of harvesting methods" section) - it was possible to compare all methods with respect to $\mathrm{HE}$ (Fig. 3).

According to Fig. 3, $\mathrm{AlCl}_{3}$ and $\mathrm{pH} 4$ presented the best $\mathrm{HEs}$ being considerably higher than those achieved by using the other two well-known flocculant agents $\left(\mathrm{FeCl}_{3}\right.$ and $\left.\mathrm{Ch}\right)$, which have shown a behavior similar to control tests. Taking into account the effect of ZP on the HE and the performance of $\mathrm{AlCl}_{3}$ on sedimentation of $M$. aeruginosa, it was expected that $\mathrm{ZP}$ of cyanobacteria treated with this compound would be in the OIVZP. However, this was not verified (Table 1) and thus other parameters besides ZP could have had influence in the harvesting process.

The rather low efficiency of cells removal determined for $\mathrm{FeCl}_{3}$ and $\mathrm{Ch}$ tests in the first hours of the process, besides the high value of $\mathrm{ZP}$, can also be associated with some other factors such as the biomass concentration and strain used, the sampling point, or the agitation applied. Comparing the work of Pei et al. (2014) with the results obtained here for $\mathrm{Ch}$,

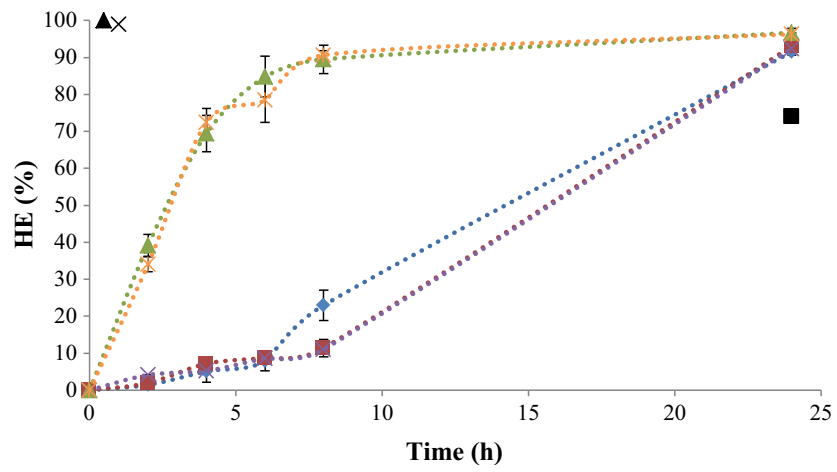

Fig. 3 Comparison of $\mathrm{HE}$ of flocculation of M. aeruginosa induced by pH $4(*), \mathrm{FeCl}_{3}(\square), \mathrm{AlCl}_{3}(\triangle)$, and $\mathrm{Ch}(\times)$ and control $(\diamond)$ on a 24-h treatment $(n=2)$. The HEs obtained in Sun et al. (2012), Chow et al. (1998), and Pei et al. (2014), from which the optimal dosage of $\mathrm{AlCl}_{3}$ $(\boldsymbol{\Delta}), \mathrm{FeCl}_{3}(\boldsymbol{\bullet})$, and $\mathrm{Ch}(\times)$ were retrieved, respectively, are also presented here. Error bars correspond to minimum and maximum values
Table 1 ZP values of the assays performed to compare the HE of all methods tested $(n=3)$

\begin{tabular}{llllll}
\hline Assay & Control & $\mathrm{pH} 4$ & $\mathrm{FeCl}_{3}$ & $\mathrm{AlCl}_{3}$ & $\mathrm{Ch}$ \\
\hline $\mathrm{ZP}(\mathrm{mV})$ & $-27.5 \pm 0.3$ & $-17.7 \pm 0.4$ & $18.5 \pm 0.2$ & $7.2 \pm 0.1$ & $15.5 \pm 0.4$ \\
\hline
\end{tabular}

it is possible to see that in that work some tests reached approximately $90 \%$ of $\mathrm{HE}$ just after $1 \mathrm{~h}$ of treatment, which is significantly higher than the values obtained in our experiments. However, the biomass concentration utilized by Pei et al. (2014) was roughly 10 times lower and an optimization of the agitation time and speed was performed, while in our study no agitation was used during the flocculation process. Additionally, the sampling point defined by Pei et al. (2014) was just $1 \mathrm{~cm}$ below the surface of the culture, which is very close to the surface relatively to ours, thus improving the values of efficiency.

\section{HE optimization-evaluation of ZP's impact}

Due to the significant differences observed for HEs found in literature and those obtained in our flocculant agents' assays (Fig. 3), together with the fact of none of the corresponding ZP values are in the OIVZP (see Table 1), led us to study the role of ZP on the harvesting of M. aeruginosa. For that purpose, several concentrations of the flocculant agents were selected in a way that it would be possible to assess the effect over the $\mathrm{HE}$ whether the ZP values applied were within, above, or below the OIVZP.

\section{$\mathrm{AlCl}_{3}$ experiments}

Besides the assay performed initially with a concentration of $15 \mathrm{mg} \mathrm{L}^{-1}$, three other concentrations of $\mathrm{AlCl}_{3}$ were tested: 1.88, 3.75, and $7.5 \mathrm{mg} \mathrm{L}^{-1}$ (Fig. 4).

Figure 4 shows that intermediate concentrations are more effective for harvesting of cyanobacteria, especially those around $3.75 \mathrm{mg} \mathrm{L}^{-1}$. Regarding the initial concentration tested $\left(15 \mathrm{mg} \mathrm{L}^{-1}\right)$, HE has improved reasonably at the beginning of the process, approximately 14 and $9 \%$ after $2 \mathrm{~h}$ and $4 \mathrm{~h}$ of treatment, respectively. Considering the relationship between $\mathrm{HE}$ and $\mathrm{ZP}$, it is possible to say that the optimal condition to promote flocculation of M. aeruginosa using $\mathrm{AlCl}_{3}$ was within the range of the OIVZP (Fig. 4).

\section{$\mathrm{FeCl}_{3}$ experiments}

The optimization of flocculation caused by the addition of $\mathrm{FeCl}_{3}$ was also carried out reducing the concentration of this agent employed initially. For that purpose, assays containing 30, 7.5, 3.75, and $1.88 \mathrm{mg} \mathrm{L}^{-1}$ of $\mathrm{FeCl}_{3}$ were conducted during $24 \mathrm{~h}$ (Fig. 5). 


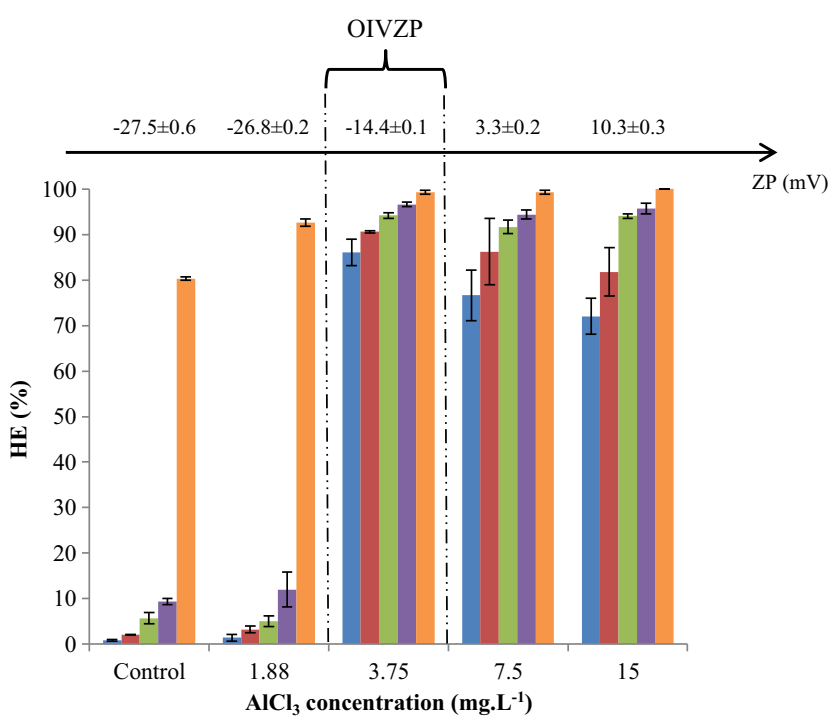

Fig. 4 HEs obtained using different concentrations of $\mathrm{AlCl}_{3}$ after $2(\square), 4$ $(\square), 6(\square), 8(\square)$, and $24 \mathrm{~h} \mathrm{(} \square)(n=2)$ and the respective $\mathrm{ZP}$ values. Error bars correspond to minimum and maximum values

Similarly to what has been verified for $\mathrm{AlCl}_{3}$, the application of $3.75 \mathrm{mg} \mathrm{L}^{-1}$ revealed to be the most suitable concentration of $\mathrm{FeCl}_{3}$ to remove $M$. aeruginosa. The improvement of the HE comparing to the results obtained with $30 \mathrm{mg} \mathrm{L}^{-1}$ of flocculant agent was noteworthy, as it increased between 85 and $88 \%$ in the first $8 \mathrm{~h}$. With respect to $\mathrm{ZP}$ and analyzing Fig. 5, these results followed the same trend exhibited previously, where values included in the range of OIVZP were associated with the highest HE.

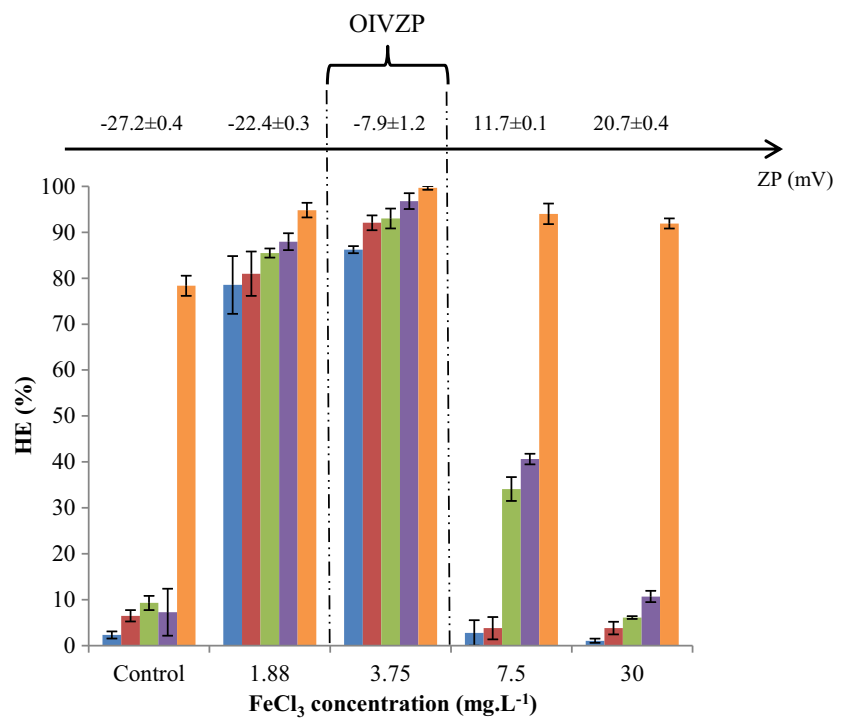

Fig. 5 Comparison of HEs using different concentrations of $\mathrm{FeCl}_{3}$ after 2 $(\square), 4(\square), 6(\square), 8(\square)$, and $24 \mathrm{~h}(\square)(n=2)$ and the respective ZP values. Error bars correspond to minimum and maximum values

\section{Ch experiments}

Maintaining the same rationale of the previous sections for the reduction of $\mathrm{ZP}$, in the assays using $\mathrm{Ch}$, it was decided to reduce concentrations $-0.25,0.5$, and $2 \mathrm{mg} \mathrm{L}^{-1}$-and compare their removal efficiency with those attained by applying $7.31 \mathrm{mg} \mathrm{L}^{-1}$, the starting point of this experiment (Fig. 6).

Although the lowest concentrations of $\mathrm{Ch}(0.25$ and $0.5 \mathrm{mg} \mathrm{L}^{-1}$ ) showed similar behavior $2 \mathrm{~h}$ after starting the harvesting process, the fact is that the use of $0.5 \mathrm{mg} \mathrm{L}^{-1}$ revealed to be a better approach reaching efficiencies above $93 \%$ at $6 \mathrm{~h}$. Once again, the increase of the HE regarding the initial assay $\left(7.31 \mathrm{mg} \mathrm{L}^{-1}\right)$ within the first $8 \mathrm{~h}$ was remarkable, varying between 65 and 76\%. The results presented in Fig. 6 also confirmed that $\mathrm{HE}$ of flocculation of $M$. aeruginosa using $\mathrm{Ch}$ is strongly dependent on $\mathrm{ZP}$ values, which means that these two parameters appear to be deeply related, regardless the flocculation derives from a $\mathrm{pH}$ change or the use of flocculant agents.

\section{Comparison of optimal conditions}

To finalize the comparison of the HE obtained for the four different methods, one last experiment was performed (Fig. 7) with the optimal conditions selected (cf. "Optimization of $\mathrm{pH}$-induced flocculation," " $\mathrm{AlCl}_{3}$ experiments," " $\mathrm{FeCl}_{3}$ experiments," and "Ch experiments" sections), ensuring that ZP of the cultures would be comprised between -6.7 and $-20.7 \mathrm{mV}$.

With no exception, the modification of $\mathrm{ZP}$ of cells enabled to reach more than $91 \%$ of $\mathrm{HE}$ in all procedures tested within the first $8 \mathrm{~h}$ (Fig. 7), being $\mathrm{FeCl}_{3}$ the most effective treatment since it has attained sedimentation rates of around $92 \%$ in $4 \mathrm{~h}$. The benefits of using ZP to favor the harvesting of cells seems

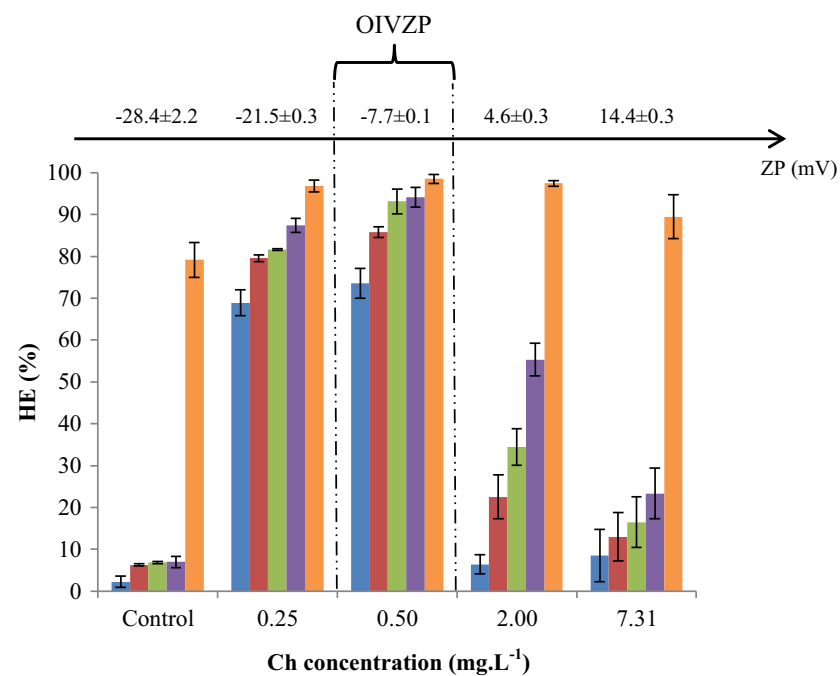

Fig. $6 \mathrm{HEs}$ of the assays performed with different concentrations of $\mathrm{Ch}$ after $2(\square), 4(\square), 6(\square), 8(\square)$, and $24 \mathrm{~h}(\square)(n=2)$ and the respective $\mathrm{ZP}$ values. Error bars correspond to minimum and maximum values 
Fig. 7 Comparison of HE under optimal conditions of flocculation of $M$. aeruginosa induced by $\mathrm{pH} 4$ (*), $\mathrm{FeCl}_{3}\left(3.75 \mathrm{mg} \mathrm{L}^{-1}\right)(\square)$, $\mathrm{AlCl}_{3}\left(3.75 \mathrm{mg} \mathrm{L}^{-1}\right)(\mathrm{N})$, and $\mathrm{Ch}$ $\left(0.5 \mathrm{mg} \mathrm{L}^{-1}\right)(\times)$ and the control $(\diamond)(n=2)$. Error bars correspond to minimum and maximum values

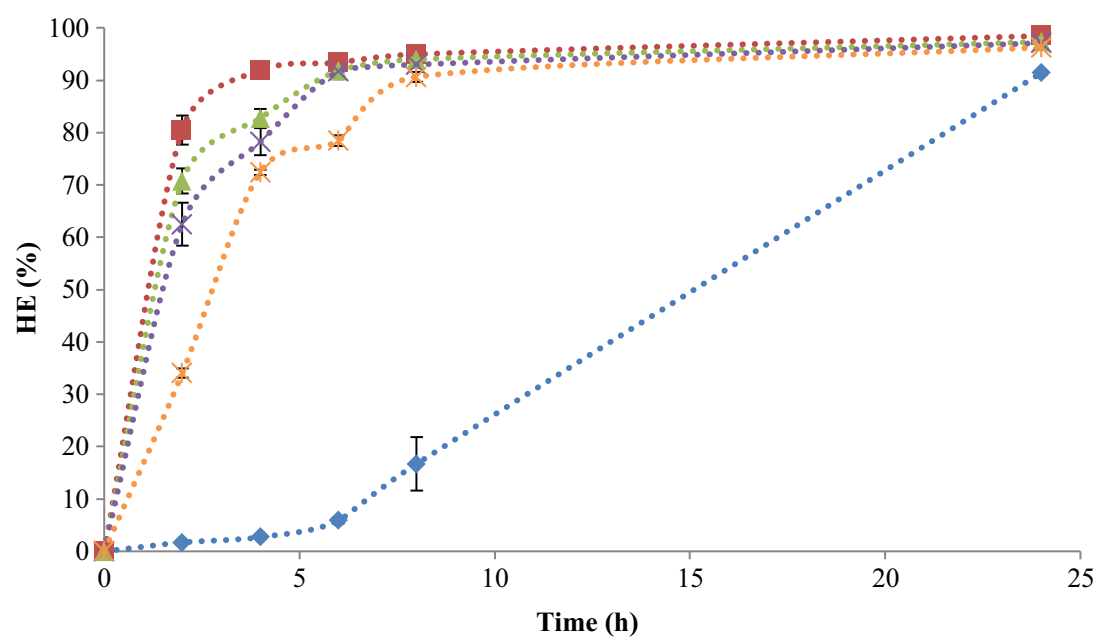

to be of utmost importance, especially if comparing these results with those obtained at the beginning of the study (Fig. 3), namely in the case of $\mathrm{FeCl}_{3}$ and $\mathrm{Ch}$.

As presented in Fig. 7, Gonzalez-Torres et al. (2014) have previously proved that the application of $\mathrm{FeCl}_{3}$ is more suitable for removal of $M$. aeruginosa than $\mathrm{AlCl}_{3}$. Regarding $\mathrm{Ch}$, Chen et al. (2014) have gathered relevant information about the harvesting of an extended group of microalgae making use of this coagulant. Although most of the harvesting efficiencies range from 80 to $95 \%$, the fact is that chitosan dosage frequently exceeds $10 \mathrm{mg} \mathrm{L}^{-1}$. Although $\mathrm{Ch}$ is seen as a very promising agent to replace metal-based flocculants such as $\mathrm{AlCl}_{3}$ and $\mathrm{FeCl}_{3}$, it also entails serious cell membranedamaging risks, which is unacceptable in the case of $M$. aeruginosa due to the release of intracellular toxins (i.e., MC). According to Mucci et al. (2017), negligible changes were observed in the normal behavior and structure of $M$. aeruginosa when subjected to low concentrations of $\mathrm{Ch}$, such as $0.5 \mathrm{~g} \mathrm{~L}^{-1}$. In contrast, dosages above $1 \mathrm{mg} \mathrm{L}^{-1}$ have demonstrated to significantly affect these cyanobacteria. In this work, we succeeded to show that it is possible to have excellent $\mathrm{HE}$ results with low concentrations of $\mathrm{Ch}$ if the conditions under which flocculation is performed are such that the adequate value of $\mathrm{ZP}$ is met.

\section{Conclusions}

Evaluation of the $\mathrm{pH}$-induced flocculation showed that the use of environments with $\mathrm{pH}$ values of 3 and 4 results in the highest HE, reaching more than $90 \%$ of cells removal within the first $8 \mathrm{~h}$ of the process.

In spite of the interference of other mechanisms, ZP has demonstrated to directly affect the HE of cyanobacteria. Generally, values within the OIVZP have proven to be the most suitable to be used in all the methods performed in this study: flocculation induced by $\mathrm{pH}, \mathrm{FeCl}_{3}, \mathrm{AlCl}_{3}$, and $\mathrm{Ch}$. The pursuit of higher HE by changing the ZP, allowed not only to improve significantly the settling rates attained utilizing the same flocculation agents (improvements ranging from 9 to $88 \%$ within the first 8 h) but also to decrease the dosage used for all of them.

Although the four harvesting methodologies have attained efficiencies higher than $91 \%$ after $8 \mathrm{~h}$, the best one revealed to be the use of $\mathrm{FeCl}_{3}$, reaching $92 \%$ within the first $4 \mathrm{~h}$ of the process.

Funding information This research work was supported by the grants SFRH/BPD/98694/2013 (Bruno Fernandes) and SFRH/BD/52335/2013 (Pedro Geada) from Fundação para a Ciência e a Tecnologia (Portugal). Luís Loureiro is recipient of a fellowship supported by a doctoral advanced training (call NORTE-69-2015-15) funded by the European Social Fund under the scope of Norte2020 - Programa Operacional Regional do Norte. This study was supported by the Portuguese Foundation for Science and Technology (FCT) under the scope of the FCT Strategic funding of UID/BIO/04469/2013 unit and COMPETE 2020 (POCI-01-0145-FEDER-006684) and BioTecNorte operation (NORTE-01-0145-FEDER-000004) funded by the European Regional Development Fund under the scope of Norte2020 - Programa Operacional Regional do Norte. This study was also supported by the Project UID/Multi/04423/2013, the Project RECI/BBB-EBI/0179/2012 (FCOMP-01-0124-FEDER-027462), and the project NOVELMAR (reference NORTE-01-0145-FEDER-000035) co-financed by the North Portugal Regional Operational Programme (Norte 2020) under the National Strategic Reference Framework (NSRF) through the ERDF.

\section{References}

Braithwaite SP, Voronkov M, Stock JB, Mouradian MM (2012) Targeting phosphatases as the next generation of disease modifying therapeutics for Parkinson's disease. Neurochem Int 61:899-906. https://doi. org/10.1016/j.neuint.2012.01.031

Chen G, Zhao L, Qi Y, Cui Y-L (2014) Chitosan and its derivatives applied in harvesting microalgae for biodiesel production: an outlook. J Nanomat 2014:217537. https://doi.org/10. $1155 / 2014 / 217537$ 
Chow CWK, House J, Velzeboer RMA, Drikas M, Burch MD, Steffensen DA (1998) The effect of ferric chloride flocculation on cyanobacterial cells. Water Res 32:808-814. https://doi.org/10. 1016/S0043-1354(97)00276-5

Geada P, Gkelis S, Teixeira J, Vasconcelos V, Vicente A, Fernandes B (2017) Chapter 17: Cyanobacterial toxins as a high added-value product. In: Muñoz R, Gonzalez C (eds) Microalgae-based biofuels and bioproducts. Woodhead Publishing, Cambridge, pp 405-432

Giannuzzi L, Sedan D, Echenique R, Andrinolo D (2011) An acute case of intoxication with cyanobacteria and cyanotoxins in recreational water in Salto Grande Dam, Argentina. Mar Drugs 9:2164-2175. https://doi.org/10.3390/md9112164

Gonzalez-Torres A, Putnam J, Jefferson B, Stuetz RM, Henderson RK (2014) Examination of the physical properties of Microcystis aeruginosa flocs produced on coagulation with metal salts. Water Res 60:197-209. https://doi.org/10.1016/j.watres.2014.04.046

Griffiths MJ, Garcin C, van Hille RP, Harrison ST (2011) Interference by pigment in the estimation of microalgal biomass concentration by optical density. J Microbiol Methods 85:119-123. https://doi.org/10. 1016/j.mimet.2011.02.005

Hadjoudja S, Deluchat V, Baudu M (2010) Cell surface characterisation of Microcystis aeruginosa and Chlorella vulgaris. J Colloid Interface Sci 342:293-299. https://doi.org/10.1016/j.jcis.2009.10. 078

Harke MJ, Stefffen MM, Gobler CJ, Otten TG, Wilhelm SW, Wood SA, Paerl HW (2016) A review of the global ecology, genomics, and biogeography of the toxic cyanobacterium, Microcystis spp. Harmful Algae 54:4-20. https://doi.org/10.1016/j.hal.2015.12.007

Ilić M, Svirčev Z, Baltić V (2011) Microcystins-potent xenobiotics. Arch Oncol 19:67-72. https://doi.org/10.2298/AOO1104067I

Jiang C, Wang R, Ma W (2010) The effect of magnetic nanoparticles on Microcystis aeruginosa removal by a composite coagulant. Colloids Surf A Physicochem Eng Asp 369:260-267. https://doi.org/10. 1016/j.colsurfa.2010.08.033

Jochimsen EM, Carmichael WW, Cardo D, Cookson ST, Holmes CEM, Antunes BC, Filho DAM, Lyra TM, Barreto VS, Azevedo SMFO, Jarvis W (1998) Liver failure and death after exposure to microcystins at a hemodialysis center in Brazil. N Engl J Med 338:873-878

Kotai J (1972) Instructions for preparation of modified nutrient solution Z8 for algae. Norwegian Institute for Water Research, Blindern, p 5

Li L, Zhang H, Pan G (2015) Influence of zeta potential on the flocculation of cyanobacteria cells using chitosan modified soil. J Environ Sci (China) 28:47-53. https://doi.org/10.1016/j.jes.2014.04.017

Lin Z, Xu Y, Zhen Z, Fud Y, Liu Y, Li W, Luo C, Ding A, Zhang D (2015) Application and reactivation of magnetic nanoparticles in Microcystis aeruginosa harvesting. Bioresour Technol 190:82-88. https://doi.org/10.1016/j.biortech.2015.04.068

Liu J, Zhu Y, Tao Y, Zhang Y, Li A, Li T, Sang M, Zhang C (2013) Freshwater microalgae harvested via flocculation induced by $\mathrm{pH}$ decrease. Biotechnol Biofuels 6:98-108. https://doi.org/10.1186/ 1754-6834-6-98

Lürling M, Noymac NP, Magalhães L, Miranda M, Mucci M, van Oosterhout F, Huszar VLM, Marinho MM (2017) Critical assessment of chitosan as coagulant to remove cyanobacteria. Harmful Algae 66:1-12. https://doi.org/10.1016/j.hal.2017.04.011

Ma M, Liu R, Liu H, Qu J, Jefferson W (2012) Effects and mechanisms of pre-chlorination on Microcystis aeruginosa removal by alum coagulation: significance of the released intracellular organic matter. Sep Purif Technol 86:19-25. https://doi.org/10.1016/j.seppur.2011.10. 015

Ma C, Hu W, Pei H, Xu H, Pei R (2016) Enhancing integrated removal of Microcystis aeruginosa and adsorption of microcystins using chitosan-aluminum chloride combined coagulants: effect of chemical dosing orders and coagulation mechanisms. Colloids Surf A
Physicochem Eng Asp 490:258-267. https://doi.org/10.1016/j. colsurfa.2015.11.056

Merel S, Walker D, Chicana R, Snyder S, Baurès E, Thomas O (2013) State of knowledge and concerns on cyanobacterial blooms and cyanotoxins. Environ Int 59:303-327. https://doi.org/10.1016/j. envint.2013.06.013

Moreira C, Vasconcelos V, Antunes A (2013) Phylogeny and biogeography of cyanobacteria and their related toxins. Mar Drugs 11:4350 4369. https://doi.org/10.3390/md11114350

Mucci M, Noyma NP, Magalhães L, Miranda M, van Oosterhout F, Guedes IA, Huszar VLM, Marinho MM, Lürling M (2017) Chitosan as coagulant on cyanobacteria in lake restoration management may cause rapid cell lysis. Water Res 118:121-130. https://doi. org/10.1016/j.watres.2017.04.020

Niedermeyer THJ, Daily A, Swiatecka-Hagenbruch M, Moscow JA (2014) Selectivity and potency of microcystin congeners against OATP1B1 and OATP1B3 expressing cancer cells. In: PLos One, vol 9, p e91476. https://doi.org/10.1371/journal.pone.0091476

Oberholster PJ, Botha A-M, Grobbelaar JU (2004) Microcystis aeruginosa: source of toxic microcystins in drinking water. Afr $\mathrm{J}$ Biotechnol 3:159-168. https://doi.org/10.5897/AJB2004.000-2029

Paerl HW, Fulton RS, Moisander PH, Dyble J (2001) Harmful freshwater algal blooms with an emphasis on cyanobacteria. Sci World J 1:76113. https://doi.org/10.1100/tsw.2001.16

Pei H-Y, Ma C-X, Hu W-R, Sun F (2014) The behaviors of Microcystis aeruginosa cells and extracellular microcystins during chitosan flocculation and flocs storage processes. Bioresour Technol 151:314 322. https://doi.org/10.1016/j.biortech.2013.10.077

Qi J, Lan H, Miao S, Xu Q, Liu R, Liu H, Qu J (2016) $\mathrm{KMnO}_{4}$ $\mathrm{Fe}(\mathrm{II})$ pretreatment to enhance Microcystis aeruginosa removal by aluminum coagulation: does it work after long distance transportation? Water Res 88:127-134. https://doi.org/10. 1016/j.watres.2015.10.004

Rodriguez-Molares A, Dickson S, Hobson P, Howard C, Zander A, Burch M (2014) Quantification of the ultrasound induced sedimentation of Microcystis aeruginosa. Ultrason Sonochem 21:12991304. https://doi.org/10.1016/j.ultsonch.2014.01.027

Shi W, Tan W, Wang L, Pan G (2016) Removal of Microcystis aeruginosa using cationic starch modified soils. Water Res 97:19-25. https:// doi.org/10.1016/j.watres.2015.06.029

Sun F, Pei H-Y, Hu W-R, Ma C-X (2012) The lysis of Microcystis aeruginosa in $\mathrm{AlCl}_{3}$ coagulation and sedimentation processes. Chem Eng J 193-194:196-202. https://doi.org/10.1016/j.cej.2012. 04.043

Teixeira MR, Rosa MJ (2007) Comparing dissolved air flotation and conventional sedimentation to remove cyanobacterial cells of Microcystis aeruginosa. Part II. The effect of water background organics. Sep Purif Technol 53:126-134. https://doi.org/10.1016/j. seppur.2006.07.001

Wang H-Q, Mao T-G, Xi B-D, Zhang L-Y, Zhou Q-H (2015) $\mathrm{KMnO}_{4}$ pre-oxidation for Microcystis aeruginosa removal by a low dosage of flocculant. Ecol Eng 81:298-300. https://doi.org/10.1016/j. ecoleng.2015.04.015

Wu Z, Zhu Y, Huang W, Zhang C, Li T, Zhang Y, Li A (2012) Evaluation of flocculation induced by $\mathrm{pH}$ increase for harvesting microalgae and reuse of flocculated medium. Bioresour Technol 110:496-502. https://doi.org/10.1016/j.biortech.2012.01.101

Yap RKL, Whittaker M, Diao M, Stuetz RM, Jefferson B, Bulmus V, Peirson WL, Nguyen AV, Henderson RK (2014) Hydrophobicallyassociating cationic polymers as micro-bubble surface modifiers in dissolved air flotation for cyanobacteria cell separation. Water Res 61:253-262. https://doi.org/10.1016/j.watres.2014.05.032

Yuan Y, Zhang H, Pan G (2016) Flocculation of cyanobacterial cells using coal fly ash modified chitosan. Water Res 97:11-18. https:// doi.org/10.1016/j.watres.2015.12.003 
Zamyadi A, MacLeod SL, Fan Y, McQuaid N, Dorner S, Sauvé S, Prévost M (2012) Toxic cyanobacterial breakthrough and accumulation in a drinking water plant: a monitoring and treatment challenge. Water Res 46:1511-1523. https://doi.org/10.1016/j.watres. 2011.11.012

Zanchett G, Oliveira-Filho EC (2013) Cyanobacteria and cyanotoxins: from impacts on aquatic ecosystems and human health to anticarcinogenic effects. Toxins 5:1896-1917. https://doi.org/10.3390/ toxins 5101896
Zhou S, Shao Y, Gao N, Zhu S, Li L, Deng J, Zhu M (2014) Removal of Microcystis aeruginosa by potassium ferrate (VI): impacts on cells integrity, intracellular organic matter release and disinfection byproducts formation. Chem Eng J 251:304-309. https://doi.org/10. 1016/j.cej.2014.04.081

Publisher's note Springer Nature remains neutral with regard to jurisdictional claims in published maps and institutional affiliations. 